\title{
FORECASTING CURRENCY RISK IN AN ENTERPRISE USING THE MONTE CARLO SIMULATION
}

\author{
Jan Kaczmarzyk \\ University of Economics in Katowice, Katowice, Poland \\ e-mail: jan.kaczmarzyk@ue.katowice.pl \\ ORCID: 0000-0002-4139-8858 \\ (C) 2018 Jan Kaczmarzyk \\ This is an open access article distributed under the Creative Commons Attribution-NonCommercial- \\ -NoDerivs license (http://creativecommons.org/licenses/by-nc-nd/3.0/)
}

DOI: $10.15611 /$ fins.2018.4.04

JEL Classification: G32

\begin{abstract}
A non-financial enterprise with receivables or liabilities denominated in a foreign currency is exposed to currency risk. Wanting to calculate a financial reserve in order to secure its receivables or liabilities, an enterprise can introduce the concept of the value at risk. To determine value at risk, an enterprise has to know the probability distribution of the future value of the receivable or the liability for a specific moment in future. Using a geometric Brownian motion to reflect exchange rate changes is among the possible solutions. The aim of the paper is to indicate that using the Monte Carlo simulation for forecasting the currency risk of an enterprise is a clear, easy-to-implement and flexible in terms of the assumptions approach. The flexibility of the Monte Carlo approach relies on the possibility to take up the assumption that the currency position changes caused by currency fluctuations have an other than normal probability distribution.
\end{abstract}

Keywords: corporate finance, financial risk, risk analysis, Monte Carlo.

\section{Introduction}

A non-financial enterprise with receivables or liabilities denominated in a foreign currency is exposed to currency risk. Wanting to calculate a financial reserve in order to secure its receivables or liabilities, an enterprise can introduce the concept of value at risk. To determine value at risk, an enterprise has to know the probability distribution of the future value of the receivable or the liability for a specific moment in future. Using a geometric Brownian motion to reflect exchange rate changes is among the possible solutions. The traditional approach (that is most often presented) to geometric Brownian motion assumes normal changes, whereas in cases of currencies these changes can be other than normal.

The aim of the paper is to indicate that using the Monte Carlo simulation for forecasting the currency risk of an enterprise is a clear, easy-to-implement and 
flexible in terms of the assumptions approach. The flexibility of the Monte Carlo approach relies on the possibility to take up the assumption that currency position changes caused by currency fluctuations have an other than normal probability distribution. The intended contribution of the paper is to promote the Monte Carlo simulation as an easy to understand risk forecasting technique. This could be an argument for smaller economic entities to introduce simulation for casual use. A case study of a currency position being a receivable of a hypothetical enterprise with a year payment horizon is presented. The case study compares the absolute value at risk of ten different currencies in which the receivable could be denominated.

\section{Forecasting market risk using a geometric Brownian motion}

Forecasting a financial risk using the historical simulation (HS) is a rather limited solution. The most important problem is the frequency of the available data. The data with daily, weekly or monthly frequency gives respectively a daily, weekly or monthly forecasting horizon. Forecasting a quarter or half a year ahead or any desired horizon with the data of limited frequency to hand can be conducted by using a geometric Brownian motion (GBM). This solution is based on the assumption that the examined financial instrument logarithmic changes are normally distributed (1). An individual who knows the mean and the standard deviation of logarithmic changes (2) of a financial asset (e.g. a receivable or a liability in a foreign currency) is able to calculate the expected value (3) and standard deviation (4) of the financial asset (or a capital allocated in the financial asset) for any given horizon (time interval) [Brigo et al. 2007, pp. 5-6, 9; Vose 2008, pp. 329-330]. The traditional approach to GBM assumes that financial asset changes are normally distributed, whereas the future value of the financial asset has a log-normal distribution [Glasserman 2004, pp. 94-95].

$$
P_{t+T}=P_{t} \exp \left\{G_{N}\left[u,\left(\mu-\frac{\sigma^{2}}{2}\right) T, \sigma \sqrt{T}\right]\right\},
$$

where: $G_{N}()$ - the inverse function of the cumulative distribution function for the normal probability distribution, $\mu-$ drift, $\sigma$ - volatility, $T$ - time interval (1 when "step by step" - day by day, week by week etc.), $P_{t}-$ financial asset value (or capital allocated in the financial asset) in the current period, $P_{t+T}$ - financial asset value (or capital allocated in the financial asset) after time interval $T, u$-a random number from the uniform distribution $(0,1)$.

$$
m=\left(\mu-\frac{\sigma^{2}}{2}\right) T, v=\sigma^{2} T,
$$


where: $m$-average value of the empirical probability distribution of the logarithmic changes (logarithmic rates of return) of the financial asset (expected rate of return), $v$-variance of the empirical probability distribution of the logarithmic changes (logarithmic rates of return) of the financial asset (expected rate of return).

$$
\begin{gathered}
E\left(P_{t+T}\right)=P_{t} \exp (\mu T), \\
S\left(P_{t+T}\right)=\sqrt{\exp (2 \mu T) P_{t}^{2}\left[\exp \left(\sigma^{2} T\right)-1\right]},
\end{gathered}
$$

where: $E\left(P_{t+T}\right)$ - the expected value of the financial asset (or capital allocated in the financial asset) after interval $T, S\left(P_{t+T}\right)$ - the standard deviation of the value of the financial asset (or capital allocated in the financial asset) after interval $T$.

The value at risk is the "worst loss over a target horizon that will not be exceeded with a given level of confidence" [Jorion 2007, p. 17]. In terms of calculating a financial reserve for a receivable or a liability in a foreign currency, the absolute VaR is an amount that covers the potential negative changes with a given probability level.

In the traditional approach, in order to calculate VaR for the financial asset (or capital allocated in the financial asset), the inverse function of the logarithmic normal distribution has to be used (7) to obtain the desired quantile. The inverse function needs arguments $(5,6)$. They can be obtained on the basis of the expected value (3) and standard deviation (4) of the financial asset in a given horizon $T$ [Vose 2008, p. 658]. Knowing the quantile and the present value or the expected value (3) of the financial asset, an individual may calculate respectively absolute (8) and relative (9) VaR [Jorion 2007, p. 108].

$$
\begin{gathered}
E_{L N}=\ln \left[\frac{E\left(P_{t+T}\right)^{2}}{\sqrt{S\left(P_{t+T}\right)^{2}+E\left(P_{t+T}\right)^{2}}}\right], \\
S_{L N}=\sqrt{\ln \left\{\left[\frac{S\left(P_{t+T}\right)}{E\left(P_{t+T}\right)}\right]^{2}+1\right\}}, \\
P_{t+T \alpha}=G_{L N}\left(\alpha, E_{L N}, S_{L N}\right),
\end{gathered}
$$

where: $E_{L N}$ - the expected value of the natural logarithms of financial asset possible values (or capital allocated in the financial asset) after interval $T, S_{L N}$ - the standard deviation of the natural logarithms of financial asset possible values (or capital allocated in the financial asset) after interval $T, P_{t+T \alpha}$ - the quantile value of the financial asset (or capital allocated in the financial asset) after interval T with a given significance level (with a given probability), $G_{L N}()-$ the inverse function of cumulative distribution function for the logarithmic normal probability distribution, $\alpha$ - significance level (given probability). 


$$
\begin{gathered}
\mathrm{VaR}_{\mathrm{A}}=P_{0}-P_{t+T_{\alpha}}, \\
\mathrm{VaR}_{\mathrm{R}}=E\left(P_{t+T}\right)-P_{t+T_{\alpha}},
\end{gathered}
$$

where: $\mathrm{VaR}_{\mathrm{A}}-$ absolute value at risk of the financial asset (or capital allocated in the financial asset) after interval $T, \mathrm{VaR}_{\mathrm{R}}$ - relative value at risk of the financial asset (or capital allocated in the financial asset) after interval $T$.

Taking into account the aim of the paper it has to be stated that the Monte Carlo approach to GBM can be easily conducted "step by step" with equal or unequal time increments [Vose 2008, pp. 330-331]. Day by day for daily empirical data, week by week for weekly empirical data and so on. In the Monte Carlo approach it is also very easy to introduce other than normal probability distribution (10). "Valuing financial assets when the world is not as normal as assumed by many financial models requires a method flexible enough to function with different distributions which, at the same time, can incorporate discontinuities such as those that arise from jump processes. The Monte Carlo method fulfills all these requirements, in addition to being accurate and efficient, which makes this numerical method the most suitable one in those cases that do not conform to normality" [Ochoa 2004, p. 1].

$$
P_{t+1}=P_{t} \exp \left[G_{B F}\left(u, \operatorname{Par}_{1}, \operatorname{Par}_{2}, \ldots, \text { Par }_{m}\right)\right],
$$

where: $G_{B F}()$ - the inverse function of the cumulative distribution function for the best fitting (to empirical) probability distribution, $\operatorname{Par}_{1}, \mathrm{Par}_{2}, \ldots, \mathrm{Par}_{m}-$ the parameters of the inverse function, $P_{t}$ - financial asset value (or capital allocated in the financial asset) in the current period, $P_{t+1}$ - financial asset value (or capital allocated in the financial asset) in the next period, $u-$ a random number from the uniform distribution $(0,1)$.

The simulation is very easy to perform on a spreadsheet. The first step is to possess empirical data on a financial asset. In cases of a receivable denominated in a foreign currency the historical currency quotations have to be gained. The next step is to choose the frequency for the step-by-step approach. For example, if the weekly frequency is chosen then the empirical data should be filtered into weekly data. After that the empirical quotations should be recalculated into logarithmic changes and their expected value and standard deviation should be obtained (2). Then the forecasting horizon should be chosen and the initial value of the financial asset (or capital allocated in the financial asset) should be set. Finally, the value of a financial asset should be calculated step-by-step (week-by-week when the weekly frequency is chosen). The process should be repeated many times to gain as many potential scenarios of the value of the financial asset in a given horizon as possible. The more scenarios, the more precise the accuracy of the simulation approach is (see: sample spreadsheet solution for the traditional and simulation approach to GBM in Figure 1).

The Monte Carlo approach is much easier in terms of the clear presentation of the problem as well as being an incomparably easier way to perform calculations of 


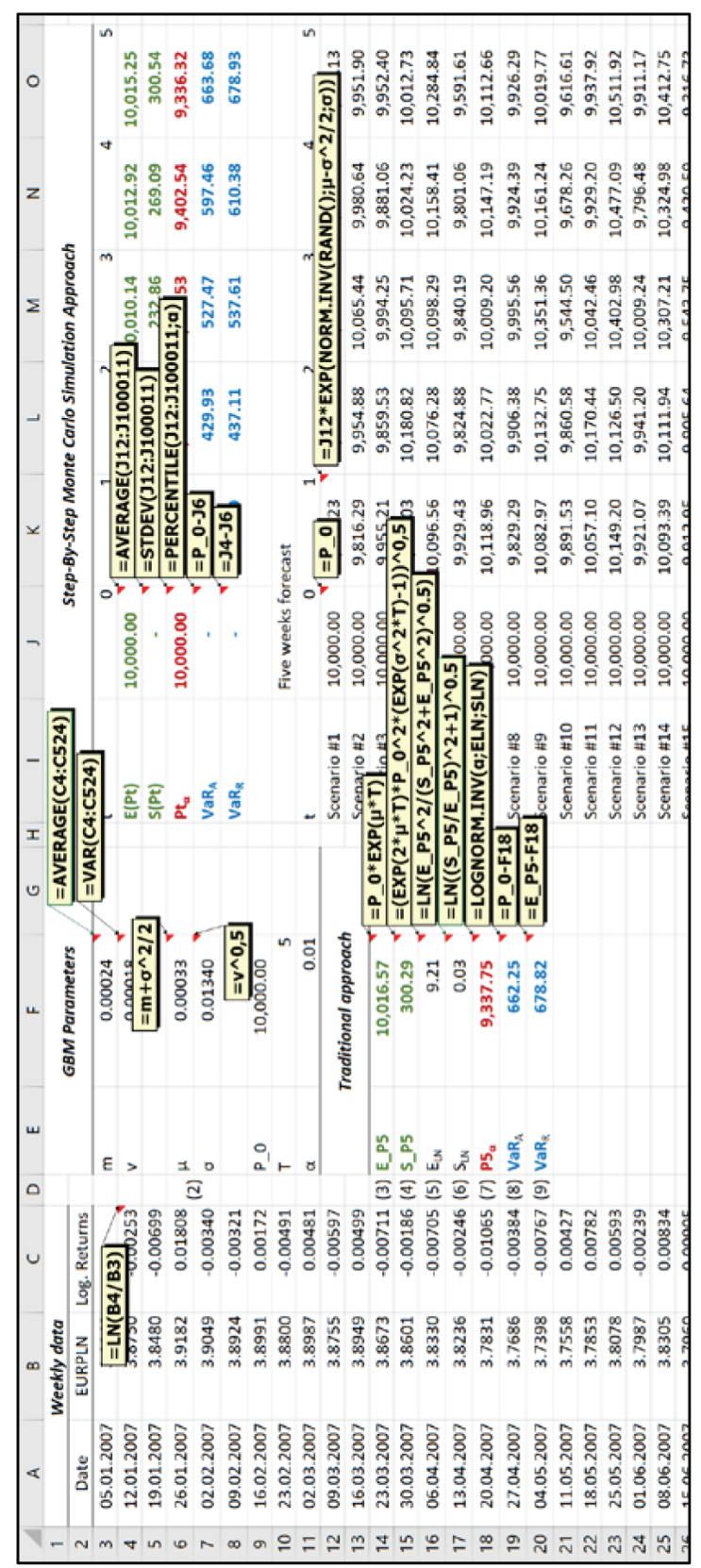

Fig. 1. An example model of the GBM - a sample spreadsheet solution for traditional and simulation approach for a five week forecast on the basis of 521 historical weeks with normal distribution assumption, 100,000 iterations

Source: own elaboration. 
VaR using spreadsheet functions (see: Figure 1). Thus, the Monte Carlo approach should be promoted as a tool suitable for individuals not having strong statistical experience whereas this experience is required for the traditional approach.

The second important problem is the type of the theoretical probability distribution. The popular approach to GBM assumes a normal probability distribution. One of the most significant disadvantages is the poor reliability in covering extreme losses [Wilmott 2006, pp. 297-299]. The logistic and hyper secant distribution are indicated, e.g. to "well fit over the entire domain of the empirical distribution, without the needing to trade off between tail and central range of the series at hand" [Bagnato et al. 2015, p. 1232]. The Monte Carlo approach enables the easy introduction of any other type of distribution. Taking into account the aim of the paper it has to be emphasized that this possibility is an important advantage of the Monte Carlo approach which proves its flexibility. The most important thing is to fit the distribution to data. This can be done using various goodness-of-fit statistics (Chi-Square, Kolmogorov-Smirnov, Anderson-Darling) or information criteria (Schwarz, Akaike, Hannan-Quinn) [Vose 2008, pp. 284-295].

No matter the method or the approach, the calculated VaR is a hypothetical, maximum, negative change in an asset with a given confidence level. Making a financial reserve equal to VaR means covering the asset potential loss with a given confidence level. The difference between absolute and relative VaR is that relative VaR covers the difference between the expected value and the present value.

\section{Case study}

A hypothetical enterprise was assumed to have a receivable in one out of the ten foreign currencies, of which the present value recalculated in a domestic currency was $10,000.00 \mathrm{PLN}$ on $31^{\text {st }}$ December 2016. The receivable is a long-term asset that is expected to be converted into a domestic currency after 52 weeks. The enterprise is going to secure the receivable by making a reserve. The reserve has to cover potential losses with $99 \%$ confidence level. The absolute Value at Risk $\left(\operatorname{VaR}_{\mathrm{A}}\right)$ was calculated for every considered foreign currency. The traditional approach and the Monte Carlo approach were used. Alongside the normal distribution, a best fitting distribution was used in the Monte Carlo approach.

On the basis of 521 weekly logarithmic changes of every currency $(01 / 05 / 2007$ $-12 / 30 / 2016$ - last ten years) an expected logarithmic change with accompanying standard deviation was calculated. Subsequently, the forecasted probability distribution of the receivable was derived using the traditional, non-simulation approach to GBM. The highest expected value of the hypothetical receivable was noted for the CHF (10,653.32 PLN), whereas the lowest-for the HUF $(9,192.74$ PLN). The expected value higher than the present value was noted for seven out of the ten considered currencies (Table 1). 
Table 1. The $\mathrm{VaR}_{\mathrm{A}}$ using the traditional approach with a normal probability distribution assumption

\begin{tabular}{|c|c|c|c|c|c|c|c|c|c|}
\hline Currency & $m$ & $\Sigma$ & $\mu$ & $E\left(P_{t+T}\right)$ & $S\left(\mathrm{P}_{t+T}\right)$ & $E_{L N}$ & $S_{L N}$ & $P_{t+T \alpha}$ & $\mathrm{VaR}_{\mathrm{A}}$ \\
\hline CHFPLN & $0.102 \%$ & $1.987 \%$ & $0.122 \%$ & $10,653.32$ & $1,534.56$ & 9.26 & 0.14 & $7,555.10$ & $2,444.90$ \\
\hline CZKPLN & $0.029 \%$ & $1.206 \%$ & $0.036 \%$ & 10,18 & 887.76 & 9.23 & 0.09 & $8,290.77$ & $1,709.23$ \\
\hline DKKPLN & $0.024 \%$ & $1.359 \%$ & $0.033 \%$ & $10,1^{\prime}$ & 999.96 & 9.22 & 0.10 & $8,061.64$ & $1,938.36$ \\
\hline EURPLN & $0.024 \%$ & $1.340 \%$ & $0.033 \%$ & $10,173.66$ & 985.67 & 9.22 & 0.10 & $8,087.09$ & $1,912.91$ \\
\hline GBPPLN & $0.021 \%$ & $1.725 \%$ & $-0.006 \%$ & $9,966.42$ & $1,244.87$ & 9.20 & 0.12 & $7,404.07$ & $2,595.93$ \\
\hline HRKPLN & $0.021 \%$ & $1.306 \%$ & $0.030 \%$ & $10,155.41$ & 958.77 & 22 & 0.09 & $8,120.78$ & $1,879.22$ \\
\hline HUFPLN & $-0.013 \%$ & $1.165 \%$ & $-0.006 \%$ & $9,966.56$ & 838.86 & 9.20 & 0.08 & $8,168.21$ & $1,831.79$ \\
\hline NOKPLN & $0.006 \%$ & $1.471 \%$ & $0.017 \%$ & $10,089.10$ & $1,073.51$ & 9.21 & 0.11 & 7,838.07 & $2,161.93$ \\
\hline UAHPLN & $-0.257 \%$ & $4.358 \%$ & $-0.162 \%$ & 9,19 & 2,96 & 9.08 & 0.31 & 4,2 & $5,788.14$ \\
\hline USDPLN & $0.065 \%$ & $2.156 \%$ & $0.088 \%$ & $10,467.52$ & $1,637.51$ & 9.24 & 0.16 & $7,202.71$ & $2,797.29$ \\
\hline
\end{tabular}

Source: own elaboration.

Taking into account that currencies change along with the traditional approach to GBM, a 1\% quantile was calculated for a 52-week horizon (Table 1). The highest quantile was noted for the CZK $(8,290.77$ PLN), whereas the lowest for the UAH $(4,211.86$ PLN). In this way it was determined that the future value of the receivable in the CZK would exceed 8,290.77 PLN with a 99\% confidence level. In the case of the UAH, the future value of the receivable will exceed 4,211.86 PLN with the same confidence level. The lower the quantile with a given confidence level, the higher the currency risk affecting the enterprise's receivable.

As a consequence, the $\mathrm{VaR}_{\mathrm{A}}$ for the receivable denominated in the CZK is 1,709.23 PLN and 5,788.14 PLN in the case of the UAH. This means that the receivable with a present value of $10,000.00$ PLN will not lose its value by respectively more than 1,709.23 PLN and 5,788.14 PLN (Table 1). Making a reserve equal to the $\mathrm{VaR}_{\mathrm{A}}$ means securing the receivable with a $99 \%$ confidence level. In other words, there is a $1 \%$ chance that the receivable will decrease by more than the value of the $\mathrm{VaR}_{\mathrm{A}}$. One should notice that the same level of security is to be achieved for the receivable denominated in the CZK with a 3.39 times lower amount.

The calculations were conducted again using the Monte Carlo approach. The first variant under consideration was the simulation with the normal probability distribution assumption ${ }^{1}$, whereas the second variant was the simulation with the assumption that the currency position changes have the probability distribution that fits best to empirical data. ${ }^{2}$ There was no normal distribution indicated in any

${ }^{1}$ The outcome provided by the Monte Carlo simulation with a normal distribution assumption in terms of forecasted currency position changes is equal to the outcome obtained with the traditional approach. It has to be mentioned that individuals with lower statistical experience could perceive the simulation approach as being much clearer.

${ }^{2}$ The theoretical distributions were fitted using the Palisade @RISK 7.5.1. All the available distributions were used. The default information criterion AIC was chosen. 
currency taken into account. In the case of five currencies it was determined that the best fitting theoretical probability distribution was hyperbolic-secant distribution (CZK, GBP, HRK, HUF, NOK). The next four currencies had the Laplace distribution (CHF, DKK, EUR, UAH). There was also one currency with logarithmic-logistic distribution (USD). The expected value and the $\mathrm{VaR}_{\mathrm{A}}$ were obtained using 100,000 iterations, the random values were generated using the Latin HyperCube technique and the Mersenne Twister random number generator. ${ }^{3}$

Table 2. The $\mathrm{VaR}_{\mathrm{A}}$ - the Monte Carlo simulation outcome with normal and best fitting probability distribution assumption

\begin{tabular}{|c|c|c|c|c|c|c|c|}
\hline \multirow[b]{2}{*}{ Currency } & \multicolumn{2}{|c|}{$E\left(P_{t+T}\right)$} & \multicolumn{2}{|c|}{$\mathrm{VaR}_{\mathrm{A}}$} & \multicolumn{2}{|c|}{ Normal vs Best Fit } & \multirow{2}{*}{$\begin{array}{c}\text { Best fitting } \\
\text { probability distribution }\end{array}$} \\
\hline & $\begin{array}{l}\text { Normal } \\
\text { MC }\end{array}$ & $\begin{array}{l}\text { BestFit } \\
\text { MC }\end{array}$ & $\begin{array}{l}\text { Normal } \\
\text { MC }\end{array}$ & $\begin{array}{l}\text { BestFit } \\
\text { MC }\end{array}$ & $E\left(P_{t+T}\right)$ & $\mathrm{VaR}_{\mathrm{A}}$ & \\
\hline CHFPLN & $10,652.59$ & $9,641.84$ & $2,450.63$ & $2,886.30$ & $10.5 \%$ & $-15.1 \%$ & \begin{tabular}{|l} 
RiskLaplace \\
$(-0.00085897,0.017752)$
\end{tabular} \\
\hline CZKPLN & $10,188.65$ & $9,836.02$ & $1,707.39$ & $1,924.49$ & $3.6 \%$ & $-11.3 \%$ & \begin{tabular}{|l|l}
$\begin{array}{l}\text { RiskHypSecant } \\
(-0.00038386,0.011505)\end{array}$ \\
\end{tabular} \\
\hline DKKPLN & $10,175.19$ & $9,951.68$ & $1,929.05$ & $2,051.88$ & $2.2 \%$ & $-6.0 \%$ & \begin{tabular}{|l|l}
$\begin{array}{l}\text { RiskLaplace } \\
(-0.00017916,0.013098)\end{array}$ \\
\end{tabular} \\
\hline EURPLN & $10,173.67$ & $9,755.34$ & $1,914.83$ & $2,219.20$ & $4.3 \%$ & $-13.7 \%$ & \begin{tabular}{|l|} 
RiskLaplace \\
$(-0.00056193,0.013083)$
\end{tabular} \\
\hline GBPPLN & $9,966.92$ & $9,743.54$ & $2,588.56$ & $2,795.52$ & $2.3 \%$ & $-7.4 \%$ & \begin{tabular}{|l|} 
RiskHypSecant \\
$(-0.00065269,0.017404)$
\end{tabular} \\
\hline HRKPLN & $10,155.30$ & $10,022.58$ & $1,866.71$ & $1,873.72$ & $1.3 \%$ & $-0.4 \%$ & \begin{tabular}{|l|} 
RiskHypSecant \\
$(-0.000032023,0.012279)$
\end{tabular} \\
\hline HUFPLN & $9,966.70$ & $9,898.93$ & $1,830.51$ & $1,802.52$ & $0.7 \%$ & $1.6 \%$ & \begin{tabular}{|l} 
RiskHypSecant \\
$(-0.00025571,0.011016)$
\end{tabular} \\
\hline NOKPLN & $10,089.22$ & $9,841.96$ & $2,163.29$ & $2,305.09$ & $2.5 \%$ & $-6.2 \%$ & \begin{tabular}{|l} 
RiskHypSecant \\
$(-0.00040881,0.014293)$
\end{tabular} \\
\hline UAHPLN & $9,194.68$ & $9,411.61$ & $5,788.54$ & $4,780.80$ & $-2.3 \%$ & $21.1 \%$ & \begin{tabular}{|l} 
RiskLaplace \\
$(-0.0017138,0.033188)$
\end{tabular} \\
\hline USDPLN & $10,467.02$ & $10,378.46$ & $2,814.71$ & $2,699.03$ & $0.9 \%$ & $4.3 \%$ & \begin{tabular}{|l} 
RiskLoglogistic \\
$(-0.1897,0.18908,16.706)$
\end{tabular} \\
\hline
\end{tabular}

Source: own elaboration.

The hierarchy of the considered currencies due to the forecasted $\mathrm{VaR}_{\mathrm{A}}$ was changed by the assumption of the best fitting probability distribution. It has to be emphasized that using the normal distribution instead of the best fitting one provided a $21.1 \%$ higher $\mathrm{VaR}_{\mathrm{A}}$ in the case of $\mathrm{UAH}$ (the $\mathrm{VaR}_{\mathrm{A}}$ equal 5,788.54 PLN for the

${ }^{3}$ The iterations were conducted using Palisade @RISK 7.5.1 as in the case of the distribution fitting. 
normal and 4,780.80 PLN for the best fitting). In cases of the CHF, CZK and EUR currencies applying the normal distribution resulted with a significantly different $\mathrm{VaR}_{\mathrm{A}}$. The $\mathrm{VaR}_{\mathrm{A}}$ derived was respectively $-15,1 \%,-11,3 \%$ and $-13,7 \%$ lower. It has to be noted that the expected value calculated with the assumption of the normal probability distribution resulted to be lower $(-2.3 \%)$ in the horizon of 52 weeks for UAH. A different situation was observed with CHF, CZK and EUR which indicated the expected value respectively of $10.5 \%, 3.6 \%$ and $4.3 \%$. What is interesting is that the outcomes were very similar for the HRK and HUF currencies.

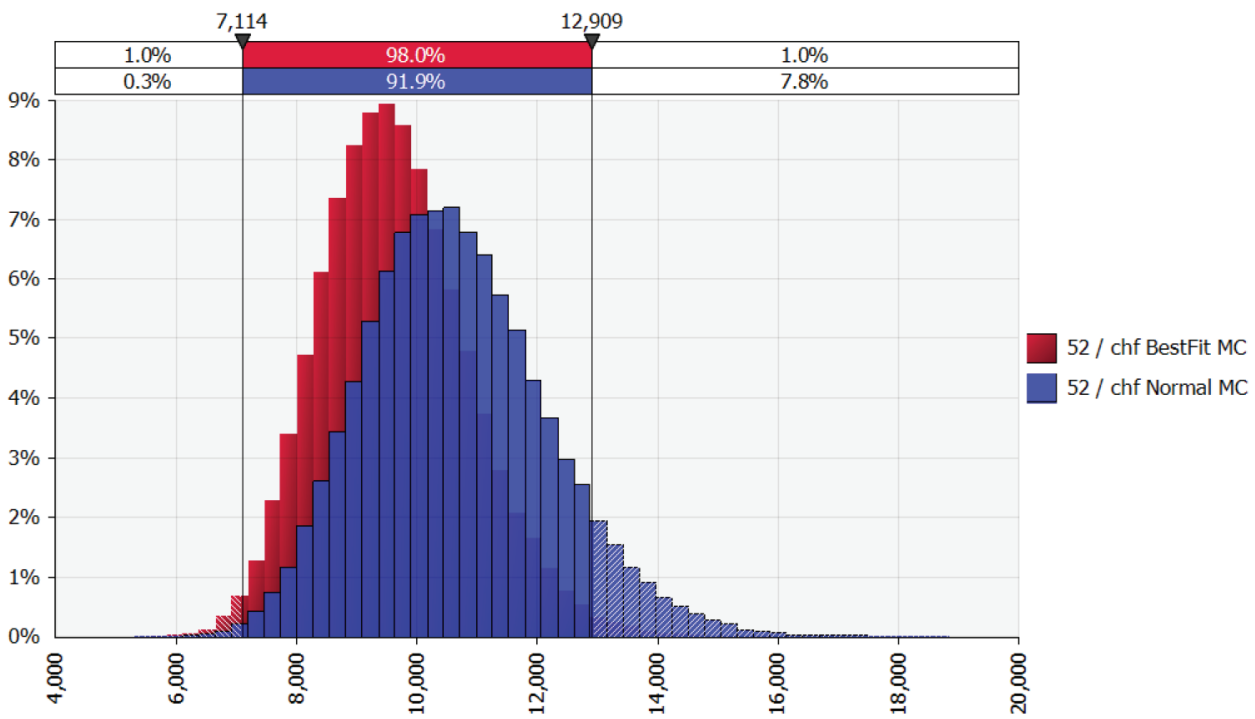

Fig. 2. The forecasted probability distribution of the receivable denominated in CHF.

The $\mathrm{VaR}_{\mathrm{A}}$ higher with the best fitting probability distribution of receivables changes over time

Source: own elaboration.

The graphical analysis of the probability distribution of the receivable future value for UAH and CHF enhances the ability of an individual to perceive the associated market risk. Using the normal probability distribution for UAH shows higher risk (Figure 3), whereas using it in the case of CHF shows a lower risk in comparison to the best fitting probability distribution (Figure 2). Using the best fitting distributions may lead to significantly different outcomes in terms of risk. Backtesting the VaR model with such a long horizon (a year) using empirical data is limited (especially in young markets). An individual may check the distribution using weekly or daily frequency (see more on the VaR backtesting in: [Hull 2012, pp. 197-200; Jorion 2007, pp. 139-157; Best 2000, p. 105]).

The basis of the calculations is empirical data. Regardless of the finally chosen approach (traditional, simulation with normal changes or simulation with best fitting 


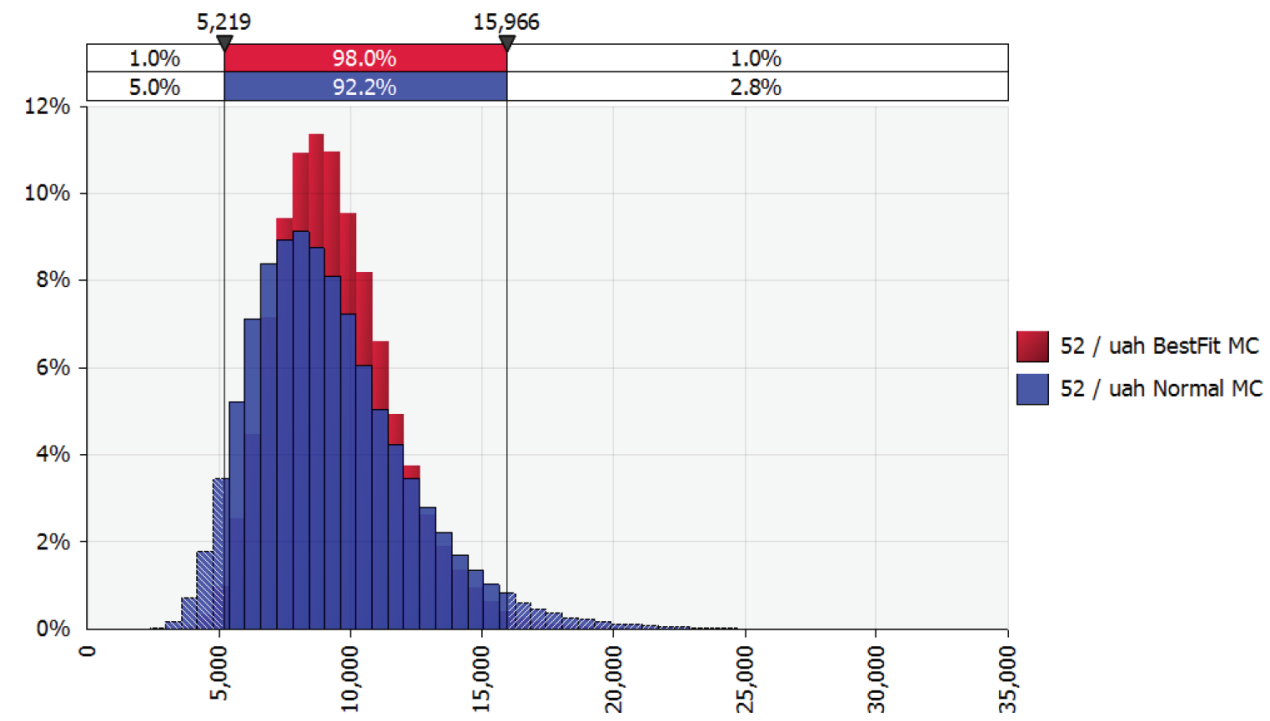

Fig. 3. The forecasted probability distribution of the receivable denominated in UAH.

The $\mathrm{VaR}_{\mathrm{A}}$ lower with the best fitting probability distribution of receivables changes over time

Source: own elaboration.

changes) the final outcomes strongly depend on the chosen historical period. In the considered case changing the assumption concerning the period of empirical data from last ten years to last five years changes the calculated VaRs significantly (Table 3).

In the shorter analysed period assuming the normal changes of the receivable nine out of the ten currencies taken into account (all but UAH) indicated the lower $\mathrm{VaR}_{\mathrm{A}}$. It should be emphasized that in the case of five currencies the difference exceeded $-25 \%$ (DKK, EUR, HRK, HUF and USD). Only for UAH, was $\mathrm{VaR}_{\mathrm{A}}$ more than $15 \%$ higher (in comparison to the outcome derived using the assumption of the last ten years). Certainly, the UAH was affected by the political crisis. Thus, shortening the empirical data caused higher VaR. The other currencies were probably affected by the financial crisis and its post-period (2007-2009). Excluding this period caused lower calculated VaRs (Table 3).

It has to be stated that the character of the empirical data period should be confronted with the expectations in terms of the forecasted period. The expected turbulent circumstances on the financial market could result with considering the significantly volatile empirical period as the basis of forecasting currency risk, which should result in avoiding underestimated VaRs. Simultaneously, excluding the turbulent period could be the solution for forecasting a steady future period in order to avoid overestimating the risk. The ultimate consequence of overestimating the risk might be higher than the required financial reserves unnecessarily affecting liquidity. 
Table 3. The $\mathrm{VaR}_{\mathrm{A}}$ using the traditional approach with a normal probability distribution assumption

\begin{tabular}{|l|r|c|r|r|r|r|c|c|c|c|}
\hline Currency & \multicolumn{1}{c|}{$m$} & $\sigma$ & \multicolumn{1}{c|}{$\mu$} & \multicolumn{1}{c|}{$E\left(P_{t+T}\right)$} & \multicolumn{1}{c|}{$S\left(P_{t+T}\right)$} & $E_{L N}$ & $S_{L N}$ & $P_{t+T a}$ & $V_{\mathrm{A}}$ & Difference \\
\hline CHFPLN & $0.043 \%$ & $1.610 \%$ & $0.056 \%$ & $10,296.83$ & $1,199.81$ & 9.23 & 0.12 & $7,806.34$ & $2,193.66$ & $-10.3 \%$ \\
\hline CZKPLN & $-0.028 \%$ & $0.908 \%$ & $-0.024 \%$ & $9,874.98$ & 647.26 & 9.20 & 0.07 & $8,461.64$ & $1,538.36$ & $-10.0 \%$ \\
\hline DKKPLN & $-0.001 \%$ & $0.891 \%$ & $0.003 \%$ & $10,015.47$ & 644.52 & 9.21 & 0.06 & $8,606.46$ & $1,393.54$ & $-28.1 \%$ \\
\hline EURPLN & $-0.005 \%$ & $0.875 \%$ & $-0.001 \%$ & $9,993.14$ & 631.14 & 9.21 & 0.06 & $8,611.75$ & $1,388.25$ & $-27.4 \%$ \\
\hline GBPPLN & $-0.014 \%$ & $1.415 \%$ & $-0.004 \%$ & $9,981.65$ & $1,021.42$ & 9.20 & 0.10 & $7,831.12$ & $2,168.88$ & $-16.5 \%$ \\
\hline HRKPLN & $-0.001 \%$ & $0.887 \%$ & $0.003 \%$ & $10,017.77$ & 641.67 & 9.21 & 0.06 & $8,614.56$ & $1,385.44$ & $-26.3 \%$ \\
\hline HUFPLN & $0.001 \%$ & $0.874 \%$ & $0.005 \%$ & $10,026.71$ & 632.70 & 9.21 & 0.06 & $8,641.84$ & $1,358.16$ & $-25.9 \%$ \\
\hline NOKPLN & $-0.066 \%$ & $1.202 \%$ & $-0.059 \%$ & $9,697.00$ & 842.21 & 9.18 & 0.09 & $7,896.26$ & $2,103.74$ & $-2.7 \%$ \\
\hline UAHPLN & $-0.389 \%$ & $5.394 \%$ & $-0.243 \%$ & $8,811.01$ & $3,560.86$ & 9.01 & 0.39 & $3,305.28$ & $6,694.72$ & $15.7 \%$ \\
\hline USDPLN & $0.075 \%$ & $1.610 \%$ & $0.088 \%$ & $10,466.23$ & $1,219.12$ & 9.25 & 0.12 & $7,935.55$ & $2,064.45$ & $-26.2 \%$ \\
\hline \multicolumn{3}{|c|}{$P 0=10,000.00, T=52$ weeks, $n=261$ weeks $(01 / 06 / 2012-12 / 30 / 2016$, stooq.pl $), \alpha=0.01$} & \\
\hline
\end{tabular}

Source: own elaboration.

Using the simulation with the best fitting probability distribution delivered divergent outcomes again (Table 4). The probability distribution fitting did not result in normal distribution for any of the considered currencies. The most frequent best fitting probability distribution appeared to be logistic distribution (five currencies EUR, GBP, HUF, NOK, USD). The second most frequent probability distribution was hyper secant distribution (three currencies - CZK, DKK, HRK). For one of the considered currencies it occurred that logarithmic logistic distribution fitted best (CHF). The case of UAH indicated the Cauchy probability distribution as the best fitting one which, in terms of the simulation, delivered unreal extreme future values $(0$ or $+\infty)$. Consequently, the Laplace distribution was assumed for UAH. It has to be stated that this distribution was marked as the best fitting one in the longer ten-year analysed historical period. Simultaneously, the probability distribution was repeated twice for CZK and HRK (Table 4).

The simulation results showed clearly that using the normal distribution in the case of CHF and UAH had brought higher $\mathrm{VaR}_{\mathrm{A}}$ (respectively $36.1 \%$ and $46.6 \%$ higher). The calculations indicated lower $\mathrm{VaR}_{\mathrm{A}}$ for most of the other considered currencies. Only in the case of HRK and NOK the simulation result was very close. Again, the highest VaRA in the case of the best fitting probability distribution was indicated for UAH (4,556.05 PLN), whereas the lowest - for HRK (1,377.85 PLN) and $\operatorname{HUF}(1,455.19$ PLN).

Both the empirical period used for the distribution fitting as well as using the best fitting distribution instead of the normal distribution have significant meaning. The normal distribution was not the best fitting one in the case of any considered currency for both of the empirical periods that had been taken into account. The best fitting probability distribution differed for the most currencies when it came to different empirical periods. 
Table 4. The $\mathrm{VaR}_{\mathrm{A}}$ - the Monte Carlo simulation outcome with the normal and best fitting probability distribution assumption

\begin{tabular}{|c|c|c|c|c|c|c|c|}
\hline \multirow{2}{*}{ Currency } & \multicolumn{2}{|c|}{$E\left(P_{t+T}\right)$} & \multicolumn{2}{|c|}{$\mathrm{VaR}_{\mathrm{A}}$} & \multicolumn{2}{|c|}{$\begin{array}{l}\text { Normal vs } \\
\text { BestFit }\end{array}$} & \multirow{2}{*}{$\begin{array}{c}\text { Best fitting } \\
\text { probability distribution }\end{array}$} \\
\hline & $\begin{array}{l}\text { Normal } \\
\text { MC }\end{array}$ & $\begin{array}{l}\text { BestFit } \\
\text { MC }\end{array}$ & $\begin{array}{l}\text { Normal } \\
\text { MC }\end{array}$ & $\begin{array}{l}\text { BestFit } \\
\text { MC }\end{array}$ & $E\left(P_{t+T}\right)$ & $\mathrm{VaR}_{\mathrm{A}}$ & \\
\hline CHFPLN & $10,297.01$ & $10,042.93$ & $2,196.21$ & $1,613.36$ & $2.5 \%$ & $36.1 \%$ & $\begin{array}{l}\text { RiskLoglogistic } \\
(-0.090425,0.08981,15.246)\end{array}$ \\
\hline CZKPLN & $9,874.89$ & $9,719.56$ & $1,533.61$ & $1,658.42$ & $1.6 \%$ & $-7.5 \%$ & $\begin{array}{l}\text { RiskHypSecant } \\
(-0.00058726,0.0089758)\end{array}$ \\
\hline DKKPLN & $10,015.56$ & $9,897.09$ & $1,391.32$ & $1,510.02$ & $1.2 \%$ & $-7.9 \%$ & $\begin{array}{l}\text { RiskHypSecant } \\
(-0.00023928,0.0089909)\end{array}$ \\
\hline EURPLN & $9,993.27$ & $9,901.63$ & $1,385.97$ & $1,459.47$ & $0.9 \%$ & $-5.0 \%$ & $\begin{array}{l}\text { RiskLogistic } \\
(-0.00022792,0.0047939)\end{array}$ \\
\hline GBPPLN & $9,981.78$ & $9,894.21$ & $2,175.24$ & $2,262.66$ & $0.9 \%$ & $-3.9 \%$ & $\begin{array}{l}\text { RiskLogistic } \\
(-0.00030715,0.0078985)\end{array}$ \\
\hline HRKPLN & $10,017.59$ & $10,061.26$ & $1,386.22$ & $1,377.85$ & $-0.4 \%$ & $0.6 \%$ & $\begin{array}{l}\text { RiskHypSecant } \\
(0.000076586,0.0090284)\end{array}$ \\
\hline HUFPLN & $10,026.68$ & $9,940.70$ & $1,353.84$ & $1,455.19$ & $0.9 \%$ & $-7.0 \%$ & $\begin{array}{l}\text { RiskLogistic } \\
(-0.00015335,0.0048714)\end{array}$ \\
\hline NOKPLN & $9,697.06$ & $9,700.89$ & $2,115.66$ & $2,089.76$ & $0.0 \%$ & $1.2 \%$ & $\begin{array}{l}\text { RiskLogistic } \\
(-0.00065601,0.00663)\end{array}$ \\
\hline UAHPLN & $8,811.76$ & $10,344.99$ & $6,681.08$ & $4,556.05$ & $-14.8 \%$ & $46.6 \%$ & $\begin{array}{l}\text { RiskLaplace } \\
(0,0.0361)\end{array}$ \\
\hline USDPLN & $10,466.08$ & $10,397.73$ & $2,066.14$ & $2,154.78$ & $0.7 \%$ & $-4.1 \%$ & $\begin{array}{l}\text { RiskLogistic } \\
(0.00061709,0.0089954)\end{array}$ \\
\hline \multicolumn{8}{|c|}{$P 0=10,000.00, T=52$ weeks, $n=261$ weeks $(01 / 06 / 2012-12 / 30 / 2016$, stooq.pl $), \alpha=0.01$} \\
\hline
\end{tabular}

Source: own elaboration.

\section{Conclusions}

An enterprise willing to introduce the VaR concept for financial reserves calculation may benefit in a much more precise picture of currency risk. Knowing the amount that covers the future volatility of a receivable or a liability which depends on foreign currency changes with a given probability level is not what an ordinary enterprise (especially small and medium) is usually going to get in terms of financial reserves calculation. The Monte Carlo approach simplifies the calculation of VaR which should be an argument for smaller economic entities suggesting a casual usage. In the Monte Carlo approach, it is also very easy to use other than normal distribution.

Taking into account the aim of the paper it has been shown that the Monte Carlo based model for forecasting currency risk can be easily developed in a spreadsheet. Such a computer model can be perceived as a flexible solution because the normal 
probability distribution can be easily replaced with any probability distribution that fits better to currency changes.

The calculations performed for the case study clearly suggest that using the normal probability distribution may undoubtedly lead to different outcomes than using the best fitting distribution. The frequently fitted distribution for the considered set of currencies was hyper secant distribution or logistic distribution in both historical periods taken into account.

\section{Bibliography}

Bagnato L., Potì V., Zoia M., 2015, The role of orthogonal polynomials in adjusting hyperbolic secant and logistic distributions to analyse financial asset returns, Statistical Papers 56(4), pp. 1205-1234 .

Best P., 2000, Wartość narażona na ryzyko, Oficyna Ekonomiczna, Kraków.

Brigo D., Dalessandro A., Neugebauer M., Triki F., 2007, A Stochastic Processes Toolkit for Risk Management, https://ssrn.com/abstract=1109160 (31.07.2017).

Glasserman P., 2004, Monte Carlo Methods in Financial Engineering, Springer, New York.

Hull J., 2012, Risk Management and Financial Institutions, 3rd Edition, John Wiley \& Sons, New Jersey.

Jorion P., 2007, Value at Risk. The New Benchmark for Managing Financial Risk, 3rd Edition, McGrawHill, Singapore.

Ochoa C., 2004, Valuation of financial assets using Monte Carlo: When the world is not so normal, Revista de Economia del Rosario, Bogotá (Colombia), 7(1), pp. 1-18.

Vose D., 2008, Risk Analysis. A Quantitative Guide, John Wiley \& Sons, West Sussex.

Wilmott P., 2006, Paul Wilmott On Quantitative Finance, 2nd Edition. John Wiley \& Sons, West Sussex.

\section{PROGNOZOWANIE RYZYKA WALUTOWEGO W PRZEDSIĘBIORSTWIE Z WYKORZYSTANIEM SYMULACJI MONTE CARLO}

Streszczenie: Przedsiębiorstwo niefinansowe posiadające należności lub zobowiązania denominowane w walucie obcej pozostaje w ekspozycji na ryzyko walutowe. W szacowaniu rezerwy finansowej, niezbędnej do zabezpieczenia swoich należności lub zobowiązań, przedsiębiorstwo może skorzystać z koncepcji wartości zagrożonej (Value at Risk). Wyznaczenie wartości zagrożonej dla należności lub zobowiązania wymaga znajomości rozkładu prawdopodobieństwa wartości przyszłej. Jednym z rozwiązań może być założenie o geometrycznym ruchu Browna kursu walutowego. Celem artykułu było wskazanie, iż zastosowanie symulacji Monte Carlo w prognozowaniu ryzyka walutowego przedsiębiorstwa jest podejściem przejrzystym, łatwym w implementacji i elastycznym w zakresie założeń. Elastyczność podejścia Monte Carlo polega na możliwości przyjęcia założenia, że zmiany pozycji walutowej przedsiębiorstwa spowodowane wahaniami kursu walutowego mają inny niż normalny rozkład prawdopodobieństwa.

Słowa kluczowe: finanse przedsiębiorstwa, ryzyko finansowe, analiza ryzyka, Monte Carlo. 